\title{
Comparative analysis of trend of change of Azerbaijan's energy sector functioning stability at the current development stage
}

\author{
Valeh Nasibov ${ }^{1}$, and Rana Alizade ${ }^{1}$ \\ ${ }^{1}$ Azerbaijan Scientific - Research and Design-Prospecting Institute of Energetics, 94, Zardabi Str., Baku, Azerbaijan
}

\begin{abstract}
Methodological and practical aspects of the trend of the change of the Azerbaijan's energy sector functioning stability in 2012-2018, based on the methodology presented by the World Energy Congress (WEC), are analyzed and considered in the paper. The basis of the methodology for the assessment of power engineering stability is the use of an energy triangle, where the vertices are energy security, environmental sustainability and energy availability, where a set of indicators with their own weighting coefficients is used to evaluate each of the subsystems. The number of indicators, and, of course, the weighting coefficients are adjusted in time in order to fully take into account all the features of the power engineering. Recalculated The values of the Azerbaijan's energy sector functioning stability during the period under review, taking into account all available indicators, some of which were not taken into account in the calculation of the WEC for the assessment of the individual subsystems, have been recalculated, due to this fact the Azerbaijan's place in the ranking of countries has moved a few positions higher.
\end{abstract}

\section{Introduction}

The trends in the change of the Azerbaijan's energy sector stability index, determined by the methodology of the World Energy Congress, is considered in the paper. The dynamics of changes in the energy sector stability for 2010-2018 are analyzed, and potentials for each of the components of sustainable energy sector are determined.

The entire world is currently plunged into a deep social and economic crisis due to the rapid spread of a new COVID-19 coronavirus, which is destroying communities and livelihood sources.

Short-term economic recovery solutions must be in line with the medium-and long-term priorities set out in The United Nations' agenda for the period to 2030 and the Paris agreement, where energy transition is considered the main means of ensuring a secure environment while achieving a healthy, prosperous, fair and sustainable future.

Due to the widespread use of innovative technologies and the reduced cost of technologies for renewable energy sources transitions to sustainable energy sector take place in many countries around the world. Sustainable energy sector provides a balance of three often contradictory goals - energy security, energy availability, and environmental sustainability. One of the tools for assessing the level of energy sustainability is the application of the methodology for determination of the Energy Sustainability Index (ESI) developed by the World Energy Congress [1-8].
The ESI is a global initiative to create a system of indicators that characterize the energy industry, by means of which the components of a country's energy sector are assessed and the energy sustainability of various countries around the world are compared.

\section{Method for determining the sustainable performance of energy}

Energy sustainability is assessed using the efficiency of the energy sector on the one hand, and the peculiarities of the state's functioning on the other hand. The energy sector functioning should provide the economy with economically feasible energy of appropriate quality, without disturbing the ecological balance. To assess energy sector stability (Energy performance dimensions), three main components are included in the energy triangle of stability: Energy security, Energy equity, Environmental sustainability, and for the assessment of the state's functioning feature (Contextual performance dimensions) the following synthetic factors are used: Macroeconomic Environment, Governance, Stability for Investment and Innovation [1-8].

It should be noted that for the assessment of energy stability, the composition of indicators in each subsystem and their weighting coefficients changed in time, as shown in Table 1.

As can be seen from Table 1, until 2016, each of the Energy Performance subsystems (Energy Security, Energy Equity, Environmental Sustainability) was 25\%, at that Country Context was 25\% [1-3]. Since 2016, the 
Table 1. Energy Trilemma Index structure and weighting.

\begin{tabular}{|c|c|c|}
\hline 2013 & \multicolumn{2}{|c|}{2019} \\
\hline \multicolumn{3}{|c|}{ ENERGY PERFORMANCE } \\
\hline Energy Security $25 \%$ & Energy Security $30 \%$ & Energy Security $30 \%$ \\
\hline $\begin{array}{l}\text { Ratio of total energy production to } \\
\text { consumption } 3.6 \%\end{array}$ & Diversity of primary energy supply $5 \%$ & $\begin{array}{l}\text { Diversity of primary energy supply } \\
6 \%\end{array}$ \\
\hline Diversity of electricity generation $3.6 \%$ & $\begin{array}{l}\text { Energy consumption in relation to GDP } \\
\text { growth } 5 \%\end{array}$ & Import dependence $6 \%$ \\
\hline $\begin{array}{l}\text { Distribution losses as a percentage of } \\
\text { generation } 3.6 \%\end{array}$ & Import dependence $5 \%$ & Diversity of electricity generation $6 \%$ \\
\hline $\begin{array}{l}\text { Five year CAGR of the ratio of TPEC to GDP } \\
3.6 \%\end{array}$ & Diversity of electricity generation $5 \%$ & Energy storage $6 \%$ \\
\hline Days of oil and oil product stocks $3.6 \%$ & Energy storage $5 \%$ & $\begin{array}{l}\text { System stability and recovery } \\
\text { capacity } 6 \%\end{array}$ \\
\hline $\begin{array}{l}\text { For importers - Net fuel imports as a } \\
\text { percentage of GDP } 3.6 \%\end{array}$ & Preparedness (human factor) $5 \%$ & \\
\hline \multicolumn{3}{|l|}{$\begin{array}{l}\text { For exporters - Fuel exports as a percentage of } \\
\text { GDP } 3.6 \%\end{array}$} \\
\hline Energy Equity $25 \%$ & Energy Equity $30 \%$ & Energy Equity 30\% \\
\hline Affordability of retail gasoline $12.5 \%$ & Access to electricity $5 \%$ & Access to electricity $6 \%$ \\
\hline \multirow[t]{6}{*}{$\begin{array}{l}\text { Affordability and quality of electricity relative } \\
\text { to access } 12.5 \%\end{array}$} & Access to clean cooking $5 \%$ & Access to clean cooking $6 \%$ \\
\hline & Quality of electricity supply 5\% & Access to "modern" energy $6 \%$ \\
\hline & $\begin{array}{l}\text { Quality of supply in urban vs. rural } \\
\text { areas 5\% }\end{array}$ & Electricity prices $3 \%$ \\
\hline & Electricity prices $3.3 \%$ & Gasoline and diesel prices 3\% \\
\hline & Gasoline and diesel prices $3.3 \%$ & Natural gas prices $3 \%$ \\
\hline & Natural gas prices $3.3 \%$ & $\begin{array}{l}\text { Affordability of electricity for } \\
\text { residents } 3 \%\end{array}$ \\
\hline Environmental Sustainability $\mathbf{2 5 \%}$ & Environmental Sustainability $\mathbf{3 0 \%}$ & Environmental Sustainability $\mathbf{3 0 \%}$ \\
\hline Total primary energy intensity $6.2 \%$ & Final energy intensity $5 \%$ & Final energy intensity $5 \%$ \\
\hline $\mathrm{CO} 2$ intensity $6.2 \%$ & $\begin{array}{l}\text { Efficiency of power generation and } \\
\text { T\&D 5\% }\end{array}$ & $\begin{array}{l}\text { Efficiency of power generation and } \\
\text { T\&D 4\% }\end{array}$ \\
\hline Effect of air and water pollution $6.2 \%$ & GHD emission trend 5\% & Low carbon electricity generation $5 \%$ \\
\hline \multirow[t]{6}{*}{$\begin{array}{l}\mathrm{CO} 2 \text { grams } / \mathrm{kWh} \text { from electricity generation } \\
6.2 \%\end{array}$} & Change in forest area $5 \%$ & GHG emissions trend $4 \%$ \\
\hline & $\mathrm{CO} 2$ intensity $3.3 . \%$ & $\mathrm{CO} 2$ intensity $2 \%$ \\
\hline & $\mathrm{CO} 2$ emission per capita $3.3 \%$ & CO2 emissions per capita $1 \%$ \\
\hline & $\mathrm{CO} 2$ from electricity generation $3.3 \%$ & CH4 emissions per capita $1 \%$ \\
\hline & & PM2.5 mean annual exposure 4\% \\
\hline & & PM10 mean annual exposure $4 \%$ \\
\hline
\end{tabular}

share of Energy Performance components has increased to $30 \%$, and Country Context has decreased to $10 \%$, respectively [4-8].

It should be noted that information on the indicators presented above is not available for all countries, therefore, for a comparative analysis of the energy sector of different countries, it has to be limited to a relatively narrow range of synthetic indicators $(8$ indicators in 2013-2015, 10 indicators in 2016-2018 and 9 indicators in 2019). While Energy Performance, according to Table 1, had to be evaluated using 12 indicators in 2013, 20 indicators in 2016, and 21 indicators in 2019.

The normalized value of each indicator, taking into account the degree of importance, is represented in the range from 0 to 10 . When assessing energy sustainability, each country receives a balance rating, where the components of the energy sustainability index are as follows: Energy security, Energy equity, Environmental sustainability are estimated by literal notations A, B, C, D, with corresponding values for A $10.00-8.01, \mathrm{~B}-8.00-5.01, \mathrm{C}-5.00-2.51$, D - $2.50-$ 0.00 . 
Table 2. Setting Word's margins.

\begin{tabular}{|l|c|c|c|c|c|c|c|}
\hline & 2013 & 2014 & 2015 & 2016 & 2017 & 2018 & 2019 \\
\hline $\begin{array}{l}\text { Energy } \\
\text { Security }\end{array}$ & 65.6 & 63.9 & 63.2 & 60.6 & 60.9 & 61.9 & 62.0 \\
\hline Energy Equity & 83.5 & 83.9 & 84.2 & 84.1 & 83.2 & 82.6 & 83.0 \\
\hline $\begin{array}{l}\text { Environmental } \\
\text { Sustainability }\end{array}$ & 63.8 & 60.1 & 59.6 & 58.8 & 61.1 & 63.3 & 63.0 \\
\hline $\begin{array}{l}\text { Trilemma } \\
\text { Score }\end{array}$ & 71.0 & 69.3 & 69.0 & 67.8 & 68.4 & 69.3 & 69.3 \\
\hline Overall Rank & 81 & 71 & 55 & 26 & 31 & 27 & 57 \\
BBC & ABD & ABC & ABA & BBA & BBA & BBB \\
\hline Key metrics & 8 & 8 & 8 & 10 & 10 & 10 & 9 \\
\hline
\end{tabular}

As can be seen from Table 2, according to the calculations of the WEC based on Key metrics for 20132019, the Energy Security value decreased by 5\% from 65.6 to 62.0 , the Energy Equity value almost did not change - 83 in 2019 against 83.5 in 2013 , as well during this period the Environmental Sustainability value decreased slightly from 63.8 to 63 . Such values of Azerbaijan's energy sector stability components are mainly related to the fact that not all indicators are used in the calculations to assess the energy components. Trends of change of some indicators for assessing Azerbaijan's energy sector sustainability are shown in Figure 1 [9-12].

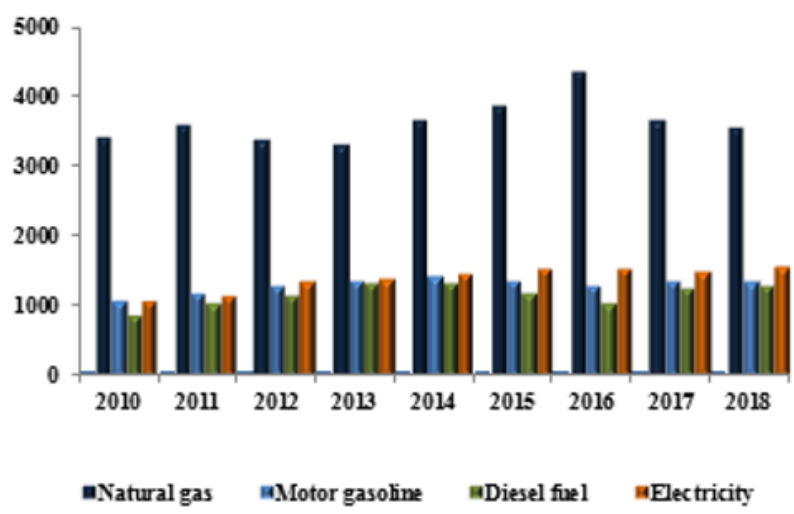

Fig. 1. Diversity of primary energy supply, thsd TOE.

As can be seen from Figure 1, Diversity of primary energy supply calculated according to Herfindahl index is about 0.21, that corresponds to high level of diversification (A) $[13,14]$.

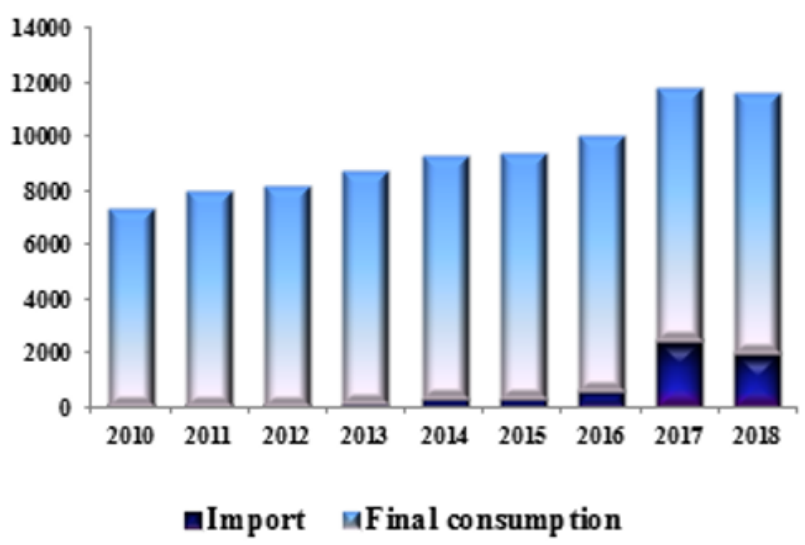

Fig. 2. Import dependence, thsd TOE.

The next indicator for assessing energy security is Import dependence. As can be seen from Figure 2, in recent years Azerbaijan has been importing a certain amount of energy resources. Since Azerbaijan is an exporter of energy resources, the purpose of energy import (natural gas) is not domestic consumption of the country, but the fulfillment of international obligations for the natural gas supply. For example, in 2019 the natural gas production in Azerbaijan was 19207. $1 \mathrm{mln}$. $\mathrm{m} 3$, of which $11076.1 \mathrm{mln} . \mathrm{m} 3$ was used for internal consumption, and exports, taking into account 1798.2 mln. m3 of imported natural gas, was $9911.8 \mathrm{mln}$. m3. Thus, this parameter for Azerbaijan corresponds to a very high level (A) [10-12].

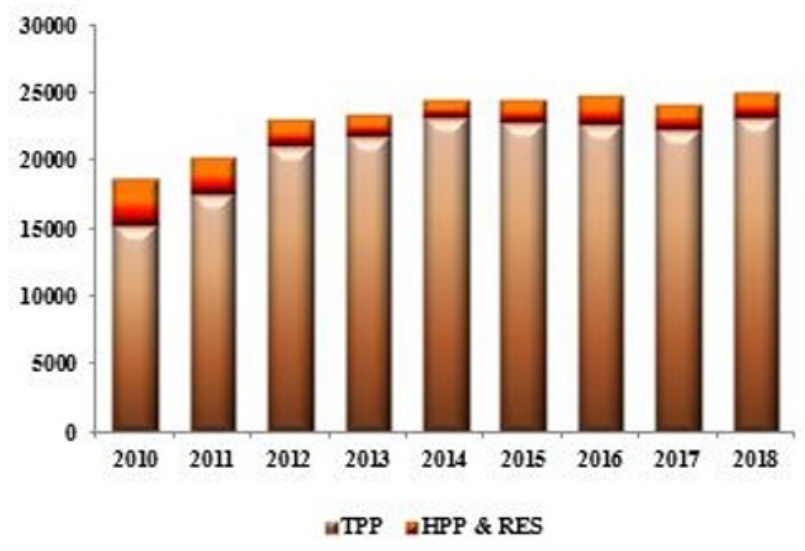

Fig. 3. Diversity of electricity generation, mln. kWh.

It should be noted that the share of HPPs and renewable energy sources in electric energy production varies in a quite large range $(2010-18.4 \%, 2014$ $5.3 \%$ ), as can be seen from Figure 3, at that in 2018 their share was $7.5 \%$. Despite the low diversification of electric energy generation, different approach is needed to this parameter, since the fuel supply of thermal power plants, where the main share of electric energy (more than $90 \%$ ) is produced, is provided at the expense of internal sources. The same approach to the assessment is required by the Energy storage indicator. 


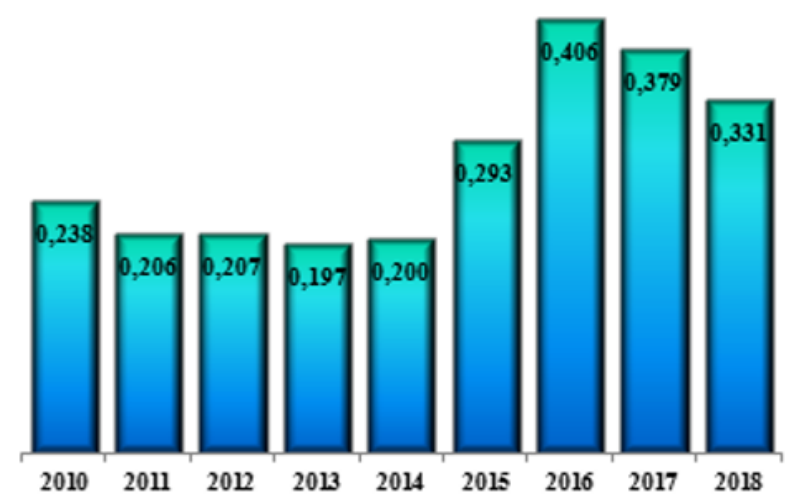

Fig. 4. Final energy intensity, TOE /1000\$.

As can be seen from Figure 4, starting from 2015 the Final energy intensity began to increase, reaching 0.406 TOE $/ 1000 \$$ in 2016 , which is related to the national currency devaluation. With the growth of Azerbaijan's GDP in the following years - 2017-2018, this indicator tends to decrease.

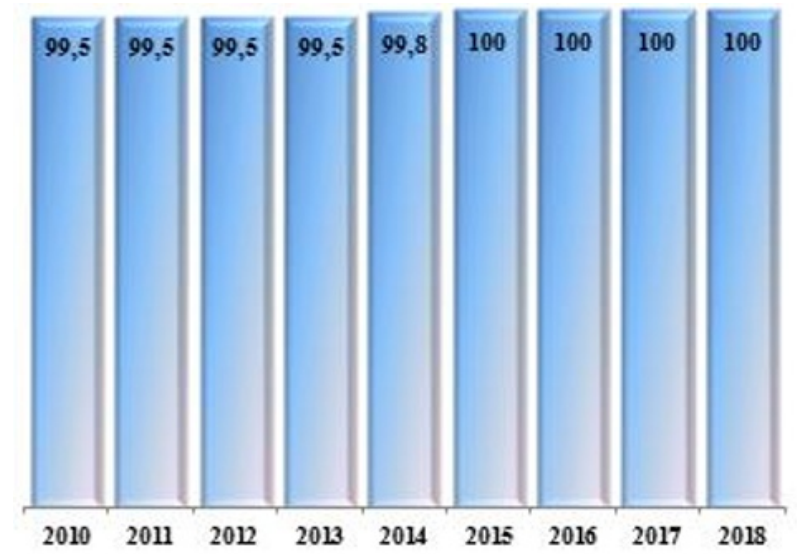

Fig. 5. Access to electricity, \%.

The state of the Access to electricity indicator is almost unchanged and is at the highest level (100\%), as shown in Figure 5. In accordance with the country's gasification level (96\%), the Access to clean cooking indicator also has a high value. It should be noted that the indicators Electricity prices, Gasoline and diesel price, Natural gas prices, Affordability of electricity for residents, which are part of the Energy Equity subsystem, also have high values. According to the calculations of the World Economic Forum, in 2019 Azerbaijan took the second place in the world on the Energy Equity subsystem.

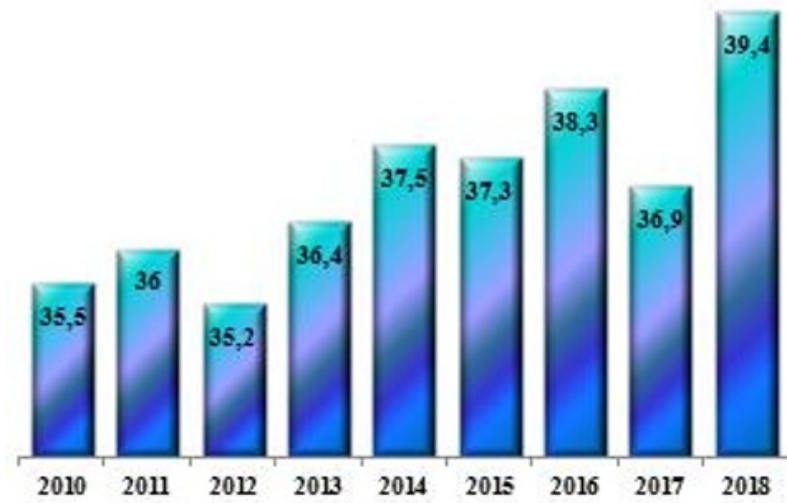

Fig. 6. Efficiency of power generation, \%.

The Efficiency of power generation varies mainly depending on the volume of power production at Azerbaijan TPP, as shown in Figure 6, as it is the most powerful and less efficient power plant in the energy system. All other thermal power plants are modern with high efficiency $(46-56 \%)[10,15,16]$.

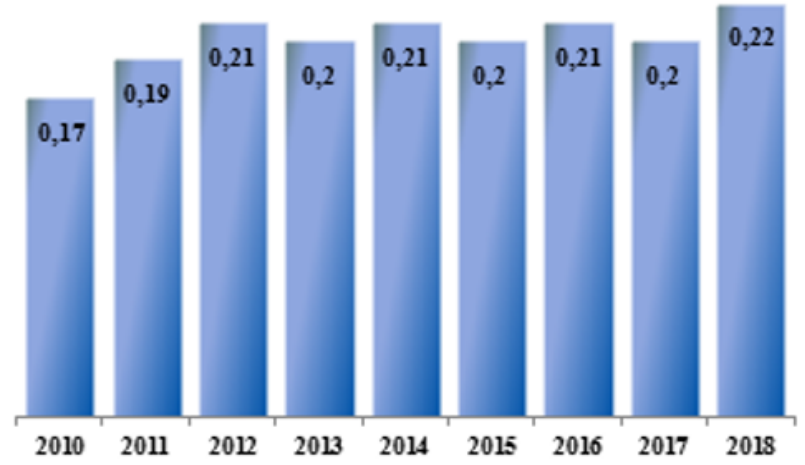

Fig. 7. $\mathrm{CO}_{2}$ intensity, tonnes per $1000 \$$ GDP.

As shown in Figure 7, during 2010-2018 period the $\mathrm{CO}_{2}$ intensity increased by about $30 \%$, although this indicator is still about $18 \%$ less than the world average indicator (0.26). Another indicator for the assessment of the Environmental Sustainability subsystem is $\mathrm{CO}_{2}$ emissions per capita, which is quite low in Azerbaijan. According to the European Commission, in 2018 the country released $34.7 \mathrm{mln}$. tons of $\mathrm{CO}_{2}$ into the atmosphere, that is, only 3.5 tons per capita, which is below the established world norm of 4.9 tons [9,10,12].

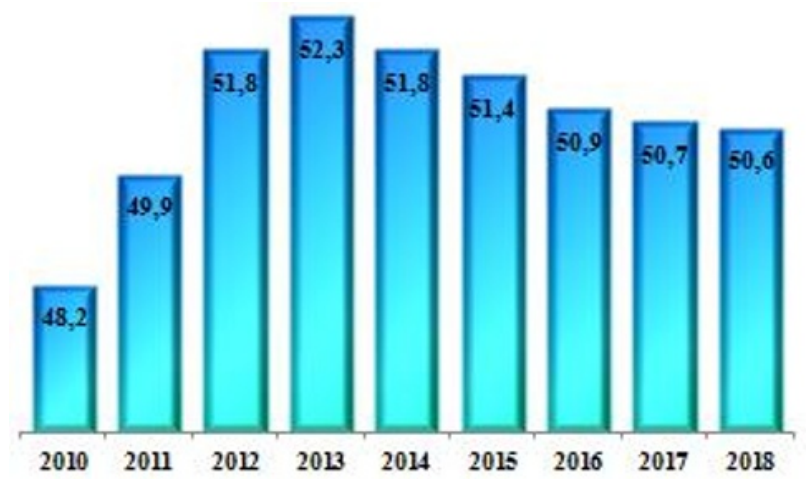

Fig. 8. GHG emissions trend, mln. tons. 
The GHG emissions trend indicator for recent years (2013-2018) has a slight but steady decrease tendency. As shown in Figure 8, during the period under review this indicator decreased by about $4 \%$.

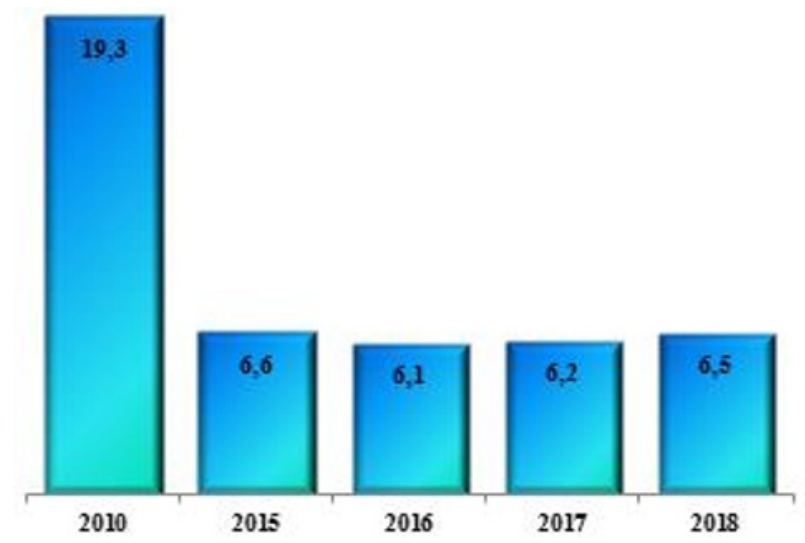

Fig. 9. PM mean annual exposure, thsd. ton.

The PM10 mean annual exposure indicator in Figure 9 has not practically changed in recent years, being at a relatively low level. The Energy Trilemma Index of Azerbaijan for 2019, constructed by the WEC with 9 key metrics and by us, taking into account 19 indicators, is presented in Figure 10 and 11. A comparative analysis of Azerbaijan's energy stability triangles shows that when all available indicators are fully taken into account, the subsystem values of energy sector have a significant difference. Energy Security increases to 78 against 62, Energy equity increases to 92 against 83 and Environmental sustainability increases to 64 against 63 . At the same time, the Trilemma Score is equal to 78 against 69.3. With such indicators Overall Rank Azerbaijan could be at 40-45 place of rating [8,9].

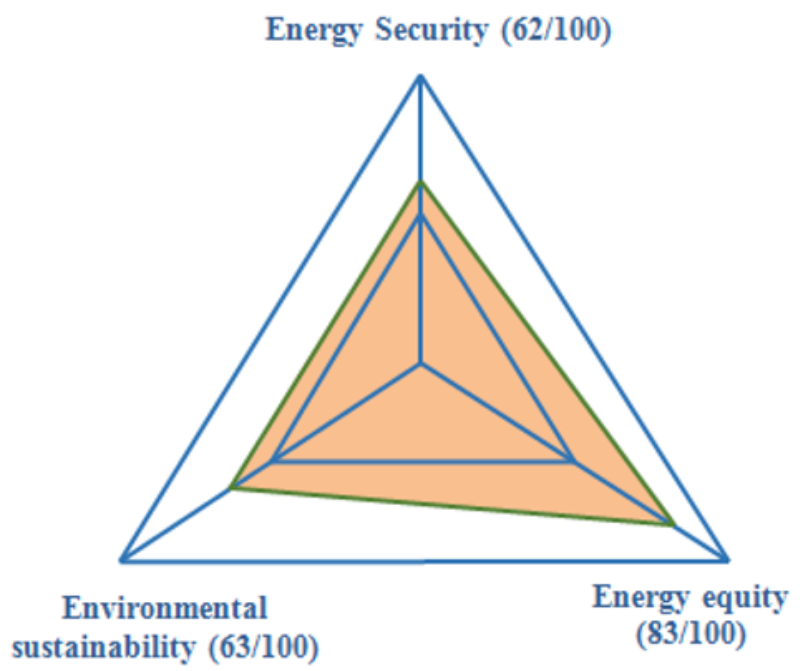

Fig. 10. Energy Trilemma Index of Azerbaijan (WEC).

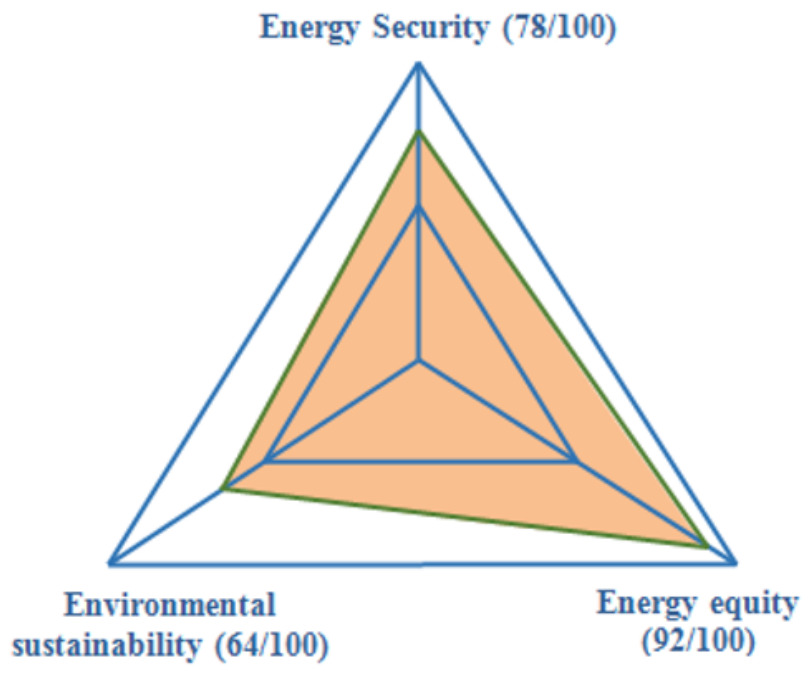

Fig. 11. Energy Trilemma Index of Azerbaijan.

\section{Conclusions}

1. The index of energy sustainability is calculated by the methods of World Energy Council on the basis of energy triangle, where the vertexes are Energy Security, Energy Equity and Environmental Sustainability.

2. With using all information about energy performance, the energy sustainability index rating of Azerbaijan will be at $40-45$ places as against 57 , by calculation of World Energy Council.

3. There are significant potentials for the improvement of status of Energy Security (78) and Environmental sustainability (64) subsystems in Energy Performance of Azerbaijan.

\section{References}

[1] World Energy Trilemma, Energy Sustainability Index [Electronic resource]. Available at: https://www.worldenergy.org/assets/images/impo rted/2013/09/2013-Energy-Sustainability-IndexVOL-2.pdf (2013)

[2] Energy Trilemma Index, Benchmarking the sustainability of national energy systems [Electronic resource]. Available at: http://www.wec-

france.org/DocumentsPDF/Etudes_CME/EnergyTrilemma-Index-2014-ENG.pdf (2014)

[3] Energy Trilemma Index, Benchmarking the sustainability of national energy systems [Electronic resource]. Available at: http://www.wec-

france.org/DocumentsPDF/Etudes_CME/2015_E nergy_Trilemma_Index.pdf (2015)

[4] World Energy Trilemma Index [Electronic resource]. Available at: https://www.worldenergy.org/assets/downloads/F ull-report_Energy-Trilemma-Index-2016.pdf (2016) 
[5] The Global Energy Architecture Performance Index 2016: Methodological Addendum [Electronic resource]. Available at: http://www3.weforum.org/docs/WEF_Energy_Ar chitecture_Performance_Index_2016.pdf (2016)

[6] World Energy Trilemma Index 2017 [Electronic resource]. Available at: https://www.worldenergy.org/assets/downloads/E nergy-Trilemma-Index-2017-Report.pdf (2017)

[7] World Energy Trilemma Index 2018 [Electronic resource]. Available at: https://www.worldenergy.org/assets/downloads/ World-Energy-Trilemma-Index-2018.pdf (2018)

[8] World Energy Trilemma Index 2019 [Electronic resource]. Available at: https://www.worldenergy.org/assets/downloads/ WETrilemma_2019_Full_Report_v4_pages.pdf (2019)

[9] N.A. Yusifbeyli, V.Kh. Nasibov, Electroenergetics, electrotechnics, electromechanics + control 4, 3, 13-23 (2013)

[10] Materials of State Statistical Committee of Azerbaijan Republic [Electronic resource]. Available at: https://www.stat.gov.az

[11] BP Statistical Review of World Energy 2019 [Electronic resource]. Available at: https://www.bp.com/content/dam/bp/businesssites/en/global/corporate/pdfs/energyeconomics/statistical-review/bp-stats-review2019-full-report.pdf (2019)

[12] World Energy Outlook 2018 [Electronic resource]. Available at: https://www.iea.org/reports/world-energyoutlook-2018 (2018)

[13] V.Kh. Nasibov, TECIS 51, 30, 405-409 (2018)

[14] V.Kh. Nasibov, TECIS 51, 30, 575-579 (2018)

[15] Clean energy for all Europeans package [Electronic resource]. Available at: https://ec.europa.eu/energy/topics/energystrategy/clean-energy-all-europeans en

[16] Renewables 2018 Global Status Report [Electronic resource]. Available at: https://www.ren21.net/wpcontent/uploads/2019/08/Full-Report-2018.pdf (2018) 